\title{
Characteristics and Prognosis of COVID-19 Induced Olfactory and Gustatory Dysfunction in Daegu
}

\author{
Sung Jae Heo ${ }^{1}$, Tae Hoon Kim², Seung-Heon Shin ${ }^{3}$, and Mi-Kyung Ye ${ }^{3}[\mathbb{C}$ \\ ${ }^{I}$ Department of Otorhinolaryngology-Head and Neck Surgery, Kyungpook National University School of Medicine, Daegu; and \\ ${ }^{2}$ Department of Otorhinolaryngology-Head and Neck Surgery, Daegu Fatima Hospital, Daegu; and \\ ${ }^{3}$ Department of Otorhinolaryngology-Head and Neck Surgery, Catholic University of Daegu School of Medicine, Daegu, Korea
}

\section{대구지역의 COVID-19 감염으로 인한 후각 및 미각장애의 특징과 예후}

허성재 ${ }^{1} \cdot$ 김태훈 $^{2} \cdot$ 신승헌 $^{3} \cdot$ 예미경 ${ }^{3}$

경북대학교 의과대학 이비인후-두경부외과학교실, ${ }^{1}$ 대구파티마병원 이비인후-두경부외과, ${ }^{2}$

대구가톨릭대학교 의과대학 이비인후-두경부외과학교실 ${ }^{3}$

Received October 8, 2020

Revised December 10,2020

Accepted December 16, 2020

Address for correspondence

Mi-Kyung Ye, MD

Department of Otorhinolaryngology-

Head and Neck Surgery,

Catholic University of

Daegu School of Medicine,

33 Duryugongwon-ro 17-gil,

Nam-gu, Daegu 42472, Korea

Tel $+82-53-650-4525$

Fax $+82-53-650-4533$

E-mail miky@cu.ac.kr
Background and Objectives Olfactory and gustatory dysfunctions have been known as characteristic symptoms of coronavirus disease 2019 (COVID-19). However, the study of the clinical features of olfactory and gustatory dysfunctions in COVID-19 is still insufficient.

Subjects and Method Mild COVID-19 patients who complained of olfactory or gustatory dysfunctions in the telephone monitoring from March 8 to April 8, 2020 were included in this study. Patient information was collected using a Google questionnaire. COVID-19 symptoms, severity and improvement of olfactory and gustatory dysfunctions of patients were investigated. Results A total of 228 patients participated in this study. The number of male and female were 76 and 152, and the average age was $32.1 \pm 11.5$ years. There were 210 patients $(92.1 \%)$ of olfactory dysfunction, 179 patients (78.5\%) of gustatory dysfunction, and 165 patients $(71.4 \%)$ who complained of both symptoms. The $18.4 \%$ of patients complained only olfactory or gustatory dysfunction without other symptoms of COVID-19, and $51.1 \%$ of patients presented olfactory and gustatory dysfunctions as the first symptoms. Most of the patients $(95.6 \%) \mathrm{im}$ proved olfactory and gustatory dysfunctions within several months, but only $79.8 \%$ of patients were normalized.

Conclusion Since olfactory and gustatory dysfunctions are the first symptoms in the numerous COVID-19 patients, and continued research on these patients play an important role in the screening and prevention of COVID-19. Long-term observation and further studies of treatment are needed for $20.2 \%$ of patients who have not fully recovered. Korean J Otorhinolaryngol-Head Neck Surg 2021;64(10):720-5

Keywords Coronavirus; COVID-19; Olfaction disorders;

Severe acute respiratory syndrome coronavirus 2; Taste disorders.

\section{서 론}

Coronavirus disease 2019(COVID-19)는 2019년 12월 중

This is an Open Access article distributed under the terms of the Creative Commons Attribution Non-Commercial License (https://creativecommons.org/licenses/by-nc/4.0) which permits unrestricted non-commercial use, distribution, and reproduction in any medium, provided the original work is properly cited.
국 우한에서 시작된 급성 바이러스성 호흡기 감염병이다. ${ }^{1)}$ 코 로나바이러스과에 속하는 바이러스에 의한 이 감염병은 이 전까지 밝혀진 감염병과 다른 양상을 보여서 처음에는 원인 병원체를 신종 코로나바이러스로 불렀지만, 현재는 severe acute respiratory syndrome coronavirus 2(SARS- $\mathrm{CoV}-2$ )로 명명되었다. 초기에는 중국, 한국 등 몇몇 국가에서만 유행했 
지만, 높은 전염성으로 유럽과 미국 등 전 세계적으로 빠르게 감염이 전파되어 $\mathrm{WHO}$ 는 2020년 3월 12일 대유행(pandemic)을 선언하였다. ${ }^{2)}$

COVID-19의 증상은 발열, 기침, 가래, 오한, 인후통, 근육 통, 두통, 전신쇠약, 설사, 콧물, 코막힘, 후각장애, 미각장애 등이 있다. ${ }^{3,4)}$ 감염병은 역학조사뿐만 아니라 증상을 바탕으 로 한 선별검사를 통해 확진자를 빠르게 찾는 것이 방역에 매우 중요하기 때문에, 많은 의학자들이 감염병의 증상에 대 한 연구를 활발히 하고 있다. 특히 COVID-19는 증상 발생 직전부터 증상이 나타나는 시점에 감염력이 가장 높아서, 증 상으로 COVID-19를 의심하는 것이 특히 중요하다. ${ }^{4)} \mathrm{COV}-$ ID-19는 새롭게 발견된 질병이기 때문에 이 병의 증상에 대 한 정보가 적었지만, 대유행을 하면서 일반적인 급성 호흡기 감염에 비해서 후각 및 미각장애 발생이 더 흔하고 심한 것 으로 알려져서 주목받고 있다. ${ }^{5-8)}$ 또한, 발열이나 기침 등 흔 한 호흡기 증상 없이 후각 및 미각장애만 호소하는 환자들도 관찰되어 이러한 증상의 발견이 방역에 중요한 역할을 할 것 으로 여겨지고 있다. ${ }^{9}$

지금까지 전세계적으로 COVID-19 환자에서 후각 및 미 각장애가 나타나는 비율이 5.1\% 98.3\%로 매우 다양하게 보 고되고 있다. ${ }^{10)}$ 이러한 차이는 인종이나 SARS-CoV-2 유전 자 염기 서열 등 다양한 원인에 의해서 나타나는 것으로 추측 된다. 국내 COVID-19 확진자 중 후각 및 미각장애의 유병 률과 임상양상을 알아보는 것은 의심환자의 선별검사와 방역 을 위해 중요하지만, 아직 이에 대한 보고는 거의 없는 상태 이다. 또한, COVID-19로 인한 후각 및 미각장애 환자의 회 복률과 후유증 여부에 대한 연구도 미흡한 상태이다. 저자들 은 국내에서 가장 큰 COVID-19 유병률이 나타난 대구지역 에서 확진된 환자 중 후각 및 미각장애 환자의 임상적인 특 징과 예후에 대해 알아보고자 하였다.

\section{대상 및 방법}

대구에서 COVID-19로 확진된 경증 환자 중 2020년 3월 8일 4월 8일까지 대구시의사회 전화모니터링에서 후각 또는 미각장애를 호소한 환자 515 명 중에서, 본 연구에 동의하며 설문지(Supplementary Material 1)를 성실히 작성한 환자를 대상으로 하였다. COVID-19 중증 감염자로 치료 중인 환자, 부비동염이나 비염 등으로 코수술 과거력이 있는 경우, 두부 외상 병력이 있는 경우, 신경퇴행성 질환이 있는 경우는 본 연 구에서 제외하였다. 본 연구는 대구공동임상연구윤리위원회 의 승인(DGIRB 2020-06-009)을 받은 후 진행되었고, 연구 에 참여한 모든 환자에서 온라인으로 동의를 받았다.
2020년 6월 16 25일까지 구글 설문지를 이용해서 환자 정 보를 수집하였고, 기저질환, 코질환 여부, COVID-19로 인한 증상, 후각 및 미각장애의 종류와 정도, 호전 여부 등에 대해 서 알아보았다. 후각 및 미각장애 정도는 visual analogue scale(VAS) 0 10점(0, 전혀 못 느낌; 10 , 정상)으로 평가하였 다. 통계는 SPSS statistics version 18.0(SPSS Inc., Chicago, $\mathrm{IL}, \mathrm{USA})$ 을 이용하여 후각 및 미각장애에서 진단 당시와 설 문조사 시점의 VAS 점수 비교를 위해 independent t-test 방 법을 사용하여 결과값을 비교하였고, 예후 분석에는 Pearson's chi-square test를 사용하였다. 연속형 변수는 기술통 계를 이용하여 표준편차와 함께 제시하였고, $p$ value가 0.05 미만인 경우 통계적으로 유의한 것으로 판단하였다.

\section{결 과}

\section{환자의 기본 정보, 감염경로 및 기저질환}

총 228명이 본 연구에 참여하였고 남자는 76명(33.3\%), 여자

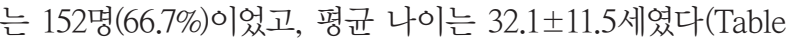
1). 대상환자의 COVID-19 확진일은 2020년 2월 20일 4월 2일 까지로 설문 조사는 환자에 따라 약 2.5 4개월 지난 시점에 이루어졌다.

환자들의 감염경로는 종교단체 등에서의 집단 감염이 78명 (34.2\%)으로 가장 많았고, 75 명(32.9\%)은 확진자와의 접촉에 의한 2 차 감염, 63 명 $(27.6 \%)$ 은 감염 경로를 알 수 없는 경우 등이었다. 기저질환은 없는 환자가 176 명 $(77.2 \%)$ 으로 가장 많

Table 1. Patient characteristics at baseline $(n=228)$

\begin{tabular}{lc}
\multicolumn{1}{c}{ Variables } & $\mathrm{n}(\%)$ \\
\hline Male/female & $76 / 152$ \\
Age (yr) & $32.1 \pm 11.5$ \\
Route of infection & $78(34.2)$ \\
$\quad$ Religious group & $75(32.9)$ \\
Secondary infection & $63(27.6)$ \\
Unknown origin & $12(5.3)$ \\
Others & \\
Underlying disease & $176(77.2)$ \\
None & $13(5.7)$ \\
Respiratory disease & $6(2.6)$ \\
Endocrine disease & $5(2.2)$ \\
Gastrointestinal disease & $12(5.3)$ \\
Smoker & \\
Nasal disease & $133(58.3)$ \\
None & $90(39.2)$ \\
Rhinitis & $14(5.7)$ \\
Sinusitis & $4(1.8)$ \\
Deviation of septum &
\end{tabular}


았고, 호흡기질환 13명(5.7\%), 내분비질환 6명(2.6\%), 소화기질 환 5명(2.2\%) 순이었으며, 흡연자는 12명(5.3\%)이었다.

후각 및 미각장애를 유발할 수 있는 기존 비강 질환을 알 아보기 위하여 이전에 병원에서 코질환이 있다고 진단받은 적이 있는지에 대한 질문에서 없음이 133명(58.3\%)으로 가장 많았고, 비염(39.2\%), 부비동염(5.7\%), 비중격 만곡(1.8\%) 등의 순이었다.

\section{환자의 증상}

후각장애는 210명(92.1\%)에서, 미각장애는 179명(78.5\%)에 서 나타났고, 후각장애와 미각장애를 동시에 호소한 경우는 165 명(72.4\%)이었다. 그 외의 증상은 피로 및 권태감(41.9\%), 발열(34.1\%), 두통(32.8\%), 기침(32.3\%), 코막힘(29.7\%), 인후통 (27.9\%), 오한(27.5\%) 콧물(21.4\%), 위장장애(10.5\%) 등이었다 (Fig. 1). 다른 증상 없이 후각 및 미각장애만 있었던 환자는 $18.4 \%$ 이었다.

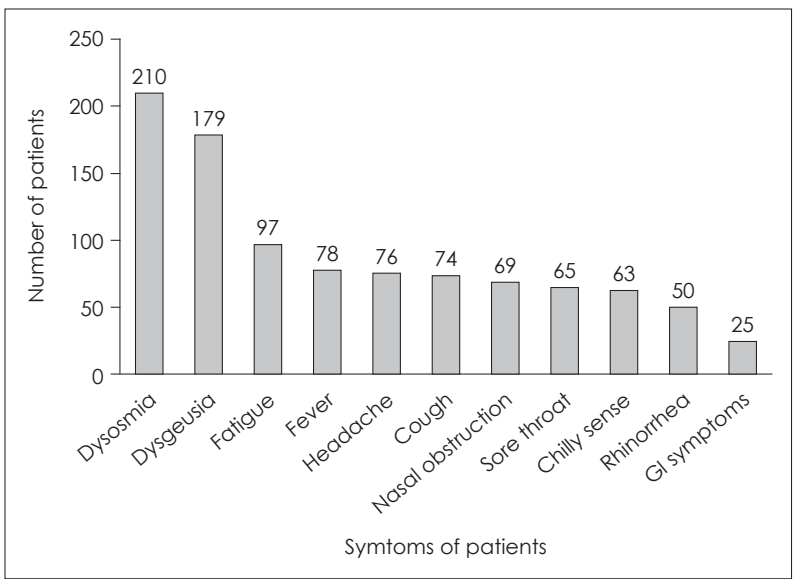

Fig. 1. Symptoms of COVID-19 patients complaining of olfactory or gustatory dysfunction. Gl: gastrointestinal.

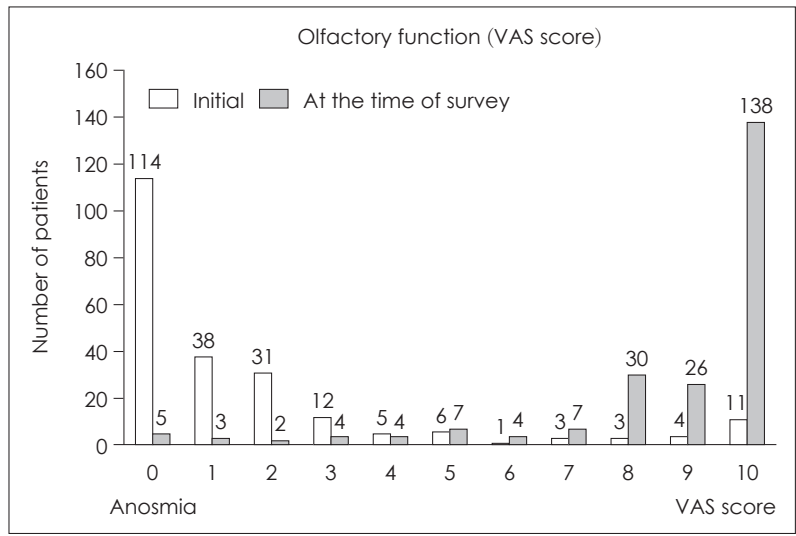

Fig. 2. Degree of olfactory function at the time of initial diagnosis of COVID-19 and at the time of survey. VAS: visual analogue scale.

\section{후각 및 미각장애의 특징과 예후}

인후통이나 발열 등의 증상이 나타나기 전에 후각 또는 미 각장애가 첫 증상으로 나타난 경우가 117 명(51.3\%)이었다. 후 각 또는 미각의 저하나 소실된 경우가 $76.8 \%$ 였고, 이상후각 (parosmia) 또는 이상미각(parageusia)은 23.2\%였다. 후각장 애 정도는 전혀 냄새를 못 맡는 VAS 0점이 $50 \%$, 1점이 $16.7 \%$, 2점이 $13.6 \%$ 로 대부분의 환자에서 심한 후각장애를 호소하 여 평균 VAS 점수는 $1.7 \pm 2.7$ 였으나, 설문조사 시점에는 VAS 8점 이상이 84.8\%이었고, 평균 8.7 \pm 2.3 점으로 유의하게 호전 되었다 $(p<0.001)$ (Fig. 2). 미각기능은 증상 발생 당시 VAS 0점이 $29.7 \%, 1$ 점은 $13.5 \%$, 2점은 $15.3 \%$ 로 평균 VAS $3.0 \pm$ 3.3점이었으며, 설문조사 시점에는 $89.9 \%$ 의 환자에서 VAS 8점 이상이었고 평균 VAS 점수는 9.1 1 1.9점으로 유의한 호 전을 보였다 $(p<0.001)$ (Fig. 3).

설문조사 시점 당시 대부분의 환자(95.6\%)에서 후각 또는 미각장애가 호전되었으며 정상으로 회복된 경우는 $79.8 \%$ 로, 나머지 $20.2 \%$ 의 환자에서는 주관적인 후각 또는 미각장애가 남아있었다. 회복된 환자들은 증상이 남은 환자들에 비해서 여자인 경우 $(p=0.001)$ 가 많았고, 평균 나이가 젊은 경우 $(p=$ 0.048)가 유의하게 많았다. 코막힘과 콧물 증상의 유무에 따 른 후각 및 미각장애 회복에는 차이가 없었고, 기저 질환과 비 강 질환 유무에서도 유의한 차이는 관찰되지 않았다(Table 2).

\section{고 찰}

COVID-19가 신종 코로나바이러스병으로 불리던 유행 초 기의 주된 증상 및 징후는 발열, 기침과 림프구 감소증, 흥부 전산화단층촬영에서 간유리음영(ground glass opacity)이 관 찰되는 것이었다.11) 초기에는 신종 감염병으로 주된 증상, 경 과, 전파, 치료 등에 대한 정보가 부족했지만, 중국에 이어서

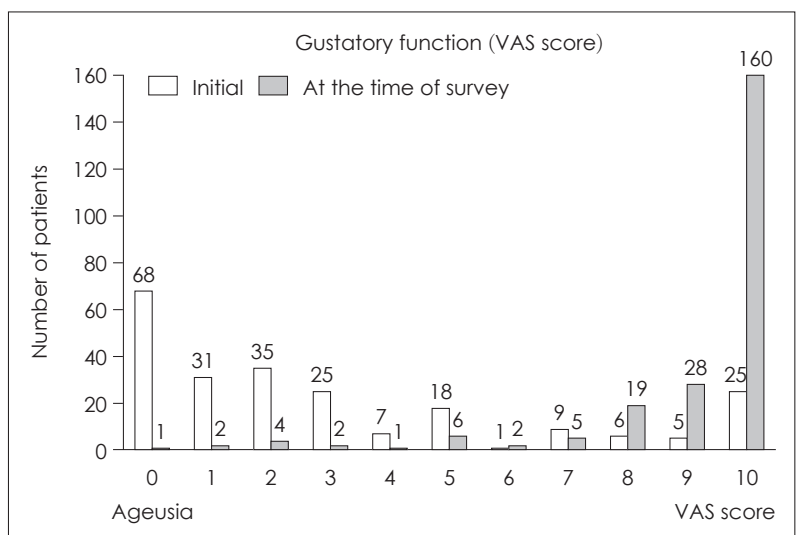

Fig. 3. Degree of gustatory function at the time of initial diagnosis of COVID-19 and at the time of survey. VAS: visual analogue scale. 
Smell and Taste Dysfunction by COVID-19 I Heo SJ, et al.

Table 2. Prognostic factors related to the recovery of olfactory or gustatory dysfunction

\begin{tabular}{lccc}
\hline \multicolumn{1}{c}{ Variables } & Complete recovery $(\mathrm{n}=182)$ & No or partial recovery $(\mathrm{n}=46)$ & $\mathrm{p}$-value \\
\hline Male/female & $59 / 123$ & $17 / 29$ & $0.001^{*}$ \\
Age $(\mathrm{yr})$ & $30.8 \pm 10.9$ & $34.13 \pm 13.5$ & $0.048^{*}$ \\
Nasal obstruction $(\mathrm{n}=69)$ & 52 & 17 & 0.284 \\
Rhinorrhea $(\mathrm{n}=50)$ & 37 & 13 & 0.239 \\
Underlying disease $(\mathrm{n}=52)$ & 38 & 14 & 0.173 \\
Nasal disease $(\mathrm{n}=95)$ & 72 & 23 & 0.242 \\
\hline
\end{tabular}

$* p<0.05$

한국, 이란, 이탈리아에서 대규모 유행하면서 질병에 대한 이 해가 높아져 갔다.

대구에서는 2020년 2월 18일을 기점으로 COVID-19 유행 이 시작되어, 2월 29일에는 741명의 새로운 확진자가 발생하 는 정점을 이루면서 격리 및 치료 병상의 부족을 초래하였다. 대구광역시 의사회의 COVID-19 대책 본부는 입원 혹은 생 활 치료소 격리의 우선 순위를 정하기 위해 전화 상담으로 중 증도를 파악하는 과정에서 상당수의 환자들이 후각과 미각 장애를 호소하는 것을 인지하게 되었다. 3 월 8 일부터 전화 상 담 중에 후각 또는 미각장애 여부에 대한 항목을 포함하여 조사한 결과 3191명의 확진자 중 $15.3 \%$ (488명)에서 후각 또 는 미각장애가 있는 것으로 보고한 바 있다. ${ }^{12)}$

외국 상황으로는 2020년 3월초 이란 비과학회에서 지난 한 달 동안 후각장애 환자가 급격히 늘었음을 알렸고, 당시에는 후각 장애 증가 원인이 COVID-19 감염 예방을 위해 손소독 제나 세척제 등 잦은 화학 물질 노출 때문일 것으로 추정했었 다. ${ }^{3)}$ 그 후 영국 비과학회와 미국 이비인후과학회에서도 후각 및 미각장애 증가의 원인이 COVID-19로 추측하는 의견들이 나왔고, 의심환자 선별조사에 후각 및 미각장애 항목을 포함 시켜야 한다고 주장하였다. 감염병의 증상은 방역에 중요하 기 때문에 그 후 여러 기관에서 COVID-19 환자에서 후각 및 미각장애 유병률을 조사하기 시작했고, 그 결과는 보고에 따 라서 다양하게 나타났다. ${ }^{10,11}$

유럽 4개 국가(벨기에, 프랑스, 스페인, 이탈리아)의 12 개 병 원 다기관 연구에서 417명의 경중-중등도 COVID-19 환자 중 후각장애는 $85.6 \%$, 미각장애는 $88.0 \%$ 에서 나타났다. ${ }^{1)}$ 이 탈리아인을 대상으로 한 연구도 COVID-19 감염자의 후각 장애는 $19.4 \%^{13}$ 에서 $75.8 \% \%^{14)}$ 로 다양하게 나타났고, 이란인을 대상으로 한 연구에서도 후각장애는 $48.23 \%^{15)}$ 에서 $98.3 \%{ }^{5)}$ 로 다양하게 보고되었다. 여러 유럽의 연구에서 COVID-19에 의 한 후각장애 비율이 30\% 70\%로 보고했지만, 중국의 $\mathrm{MaO}$ 등 4 은 $5.1 \%$ 로 보고하였고, 한국은 $15.3 \%$ 로 보고하여, 아시아 에서는 유럽에 비해서 후각장애 발생 빈도가 낮았다. 이러한 차이는 인종별 차이 및 각 국가별로 유행하는 SAR-CoV-2의 유전자형 차이나 변이 등에 의해 발생할 수 있고(유럽과 미국
은 $\mathrm{A}$ 와 $\mathrm{C}$ 형, 동양에서는 $\mathrm{B}$ 형이 유행), ${ }^{11)}$ 연구기간이 후각 및 미각장애에 대한 인식이 있던 시기인지 여부, 연구마다 후각 장애의 정의에 차이 등에 의해서 다양한 결과가 나타났을 것 으로 추측된다.

COVID-19에 의한 후각 및 미각장애 유병률이 인종 및 나 라별 차이가 크기 때문에, 적절한 국내 방역 시스템 구축을 위해서는 많은 국내 환자 대상의 연구가 필요하다. 국내 연구 로는 현재 경증 환자 전화모니터링 자료를 바탕으로 하여 후 각 및 미각장애의 유병률과 지속 기간에 대해 보고된 바 있지 만, ${ }^{12)}$ 후각 및 미각장애의 정도와 특성을 파악하기 어렵다는 한계가 있었다. COVID-19와 같이 전염성이 강한 질환은 대 면 진료와 검사가 어렵기 때문에 비대면 설문 조사에 의존할 수밖에 없으며, 설문 항목이 정교하게 구성되어야 좀 더 정확 한 정보를 얻을 수 있다. 저자들은 COVID-19 감염으로 발 생한 후각 및 미각장애의 특징과 예후를 좀 더 정확하게 파 악할 수 있는 설문지를 개발하였고, 대구지역 환자들에게 적 용하여 그 특징을 분석하였다.

본 연구에서 후각 및 미각장애가 있는 환자들은 COVID-19 의 대표적인 증상인 열이나 기침 증상 또한 대부분 동반되었 을 것으로 예상했지만, 열은 $34.1 \%$, 기침은 $32.3 \%$ 에서만 관찰 되었고, 피로 및 권태감이 $41.9 \%$ 로 후각 및 미각장애 외의 증 상으로는 가장 높은 빈도로 나타났다. 다른 증상 없이 후각 및 미각 장애만 있었던 환자가 $18.4 \%$ 로, Dell'Era 등한연구 의 $0.8 \%$ 에 비해 높게 나타났다.

기존 코질환이 없었던 환자가 많았지만 환자의 $39.2 \%$ 에서 비염, $5.7 \%$ 에서 부비동염, 비중격 만곡증이 $1.8 \%$ 에서 있었으 며, 후각 및 미각장애가 이들 기저질환으로 인한 것인지 $\mathrm{CO}-$ VID-19로 인한 것인지의 구분을 위해 후각 및 미각장애를 처음 인지한 시점, 환자가 생각하는 후각 및 미각장애의 원인, 이전에도 감기 등으로 인하여 비슷한 장애를 경험한 적이 있 는지에 대한 항목을 추가하여 분석하였다. 그 결과 비염과 부 비동염으로 진단받은 적이 있었던 환자지만 조사 당시의 후각 및 미각장애는 COVID-19로 인한 것임을 확인할 수 있었다.

바이러스에 의한 급성 상기도 감염은 콧물, 코막힘 등의 증 상을 유발함으로써 전도성 장애를 초래할 수 있을 뿐만 아니 
라, 후각 상피세포 손상에 의한 감각신경성 장애도 유발할 수 있다. COVID-19로 인한 후각 및 미각장애는 3주내에 대부 분 회복되었으며, 후각장애는 평균 7일(4.0 11.0일), 미각장애 는 6일(3.0 10.0일) 만에 회복되었다고 보고된 바 있다. ${ }^{12)}$ 본 연구에서는, 콧물, 코막힘 등의 동반증상 유무를 파악하여 전 도성 장애의 가능성을 파악하고자 하였다. 그 결과 코막힘은 $29.7 \%$, 콧물은 $21.4 \%$ 의 환자에서 동반되었던 것으로 나와서 후각 또는 미각기능이 단기간 내에 완전히 회복된 환자들 중 의 일부는 감각신경성 장애보다는 비점막과 후열부의 종창이 나 분비물로 인한 전도성 장애의 가능성을 생각해 볼 수 있 었다. 하지만, 완전히 회복된 군과 일부 기능 장애가 남았던 군을 비교해 보았을 때 코막힘과 콧물 유무는 회복 정도와 유의한 관계를 보이지 않아서 감각신경성 장애의 가능성이 더 클 것으로 생각한다(Table 2).

본 연구에서 후각장애를 심하게 느낀 환자(VAS 3점 이하) 가 $85.6 \%$ 로 높았고, 미각장애도 VAS 3점 이하가 $69.0 \%$ 로 높 았지만 설문조사 시점에 대부분의 환자(95.6\%)에서 증상이 호전되었다. 그러나 VAS를 사용한 주관적 평가이긴 하지만 정상으로 회복된 경우는 $79.8 \%$ 에 불과하여 $20.2 \%$ 의 환자에 서는 후각 및 미각장애가 일부 남아있었다. 연구자들마다 COVID-19의 다양한 후각 및 미각장애 회복률을 보고했는 데, 유럽의 다기관 연구에서는 $96.7 \%$ 환자에서 2주이내 회복 되었고, ${ }^{1)}$ 영국의 한 연구에서는 1주 후 $80 \%$ 에서 회복되었다. ${ }^{17)}$ 대부분의 기존 연구들에서는 후각 및 미각장애를 '있다', '없 다로만 분석했지만, 본 연구에서는 후각 및 미각장애의 정도 를 VAS를 사용하여 분석하여 이전 연구들에 비해 환자가 느 끼는 불편감의 정도를 좀 더 세밀하게 반영할 수 있고, 호전 정도도 좀 더 세분화 할 수 있는 장점이 있다. 전염력이 없어 진 후에 후각 및 미각 검사를 해서 대조해 본다면 좀 더 정확 한 결과를 알 수 있을 것으로 생각된다.

COVID-19의 첫 증상이 후각 또는 미각장애로 나타난 환 자 비율은 전체 확진자를 대상으로 한 연구에서는 $11.8 \%$ 로 보고되었고, ${ }^{1}$ 후각 및 미각장애 환자들만을 대상으로 한 연 구에서는 Kaye 등 ${ }^{18}$ 은 $26.6 \%$, 본 연구에서는 $51.1 \%$ 로 비교적 높게 나타나서, COVID-19 방역을 위한 선별검사에서 후각 및 미각장애에 주의할 필요가 있다. 하지만, 환자의 피로 및 전신쇠약으로 인해서 후각 및 미각장애를 느끼는 것으로 착 각할 수 있어서, 후각 및 미각장애를 확인하는 적절한 방법을 개발하는 것이 필요하다. 국내에서 많이 사용하는 Korean Version of Sniffin' Stick는 감염병 환자에서 사용하기 어렵 고, University of Pennsylvania Smell Identification Test (UPSIT)과 같은 1 회용 후각검사가 좋다. 하지만, UPSIT는 40 가지 종류의 냄새에 대한 검사로, 많은 환자를 대상으로 하는
선별검사로 사용하기에는 시간 및 경제적인 문제점이 있으므 로 좀 더 간편한 1회용 후각검사 방법 개발이 COVID-19 방 역에 도움될 것으로 보인다.

본 연구의 한계점으로, 먼저 후향적 연구로 후각 및 미각장 애에 대한 세밀한 정보를 얻기는 힘들었고 추적 관찰한 자료 도 충분히 얻기 어려워서 예후에 대한 분석이 부족하다. 또한, 아직 치료제가 없는 감염병으로 검사를 시행하기 어려웠고, 유행 중인 시점이라서 개인 정보 등의 문제로 정보를 수집하 는 것에 한계가 있었다. 마지막으로 본 연구에 포함된 환자들 은 대부분이 젊은 환자들이어서 연령에 따른 세분화된 분석 이 되지 못하였다. 따라서, 앞으로 전향적으로 다양한 연령이 포함된 후속 연구가 필요할 것으로 생각된다.

대구지역 COVID-19 감염 후 발생한 후각 및 미각장애는 종교단체 등을 통한 집단 감염과 확진자와의 접촉에 의한 2 차 감염으로 대유행하게 되었으며, 후각 및 미각장애가 다른 상 기도 감염 증상 없이 단독으로 있었거나 다른 증상이 발생하 기 전에 첫 증상으로 있었던 경우가 많아, 후각 및 미각장애 여부를 면밀히 모니터링하는 것이 전염병 전파를 막는 데 도 움이 될 것으로 생각된다. 후각 및 미각장애의 정도는 중등고도 이상의 소실을 나타냈지만 대부분 호전을 보였다. 그러 나 정상 기능 회복이 안 된 환자가 약 $20 \%$ 로 이들에 대한 장 기적인 추적 관찰 및 치료가 이루어져야 할 것으로 생각한다.

\section{Supplementary Materials}

The Data Supplement is available with this article at https://doi. org/10.3342/kjorl-hns.2020.00948.

\section{Acknowledgments}

This work was supported by the Research Program of Medicity Daegu Council funded by Daegu Metropolitan City (Fund Code COVID19_DM14).

\section{Author Contribution}

Conceptualization: Sung Jae Heo, Seung-Heon Shin, Mi-Kyung Ye. Data curation: all authors. Formal analysis: all authors. Funding acquisition: Sung Jae Heo, Tae Hoon Kim, Mi-Kyung Ye. Investigation: Sung Jae Heo, Seung-Heon Shin, Mi-Kyung Ye. Methodology: all authors. Project administration: Mi-Kyung Ye. Supervision: Seung-Heon Shin, Mi-Kyung Ye. Validation: Mi-Kyung Ye. Visualization: Sung Jae Heo. Writing — original draft: Sung Jae Heo. Writing - review \& editing: Mi-Kyung Ye.

\section{ORCID}

Mi-Kyung Ye https://orcid.org/0000-0003-3732-9670

\section{REFERENCES}

1) Lechien JR, Chiesa-Estomba CM, De Siati DR, Horoi M, Le Bon $\mathrm{SD}$, Rodriguez A, et al. Olfactory and gustatory dysfunctions as a clinical presentation of mild-to-moderate forms of the coronavirus disease (COVID-19): A multicenter European study. Eur Arch Otorhinolaryngol 2020;277(8):2251-61. 
2) Cucinotta D, Vanelli M. WHO declares COVID-19 a pandemic. Acta Biomed 2020;91(1):157-60.

3) Lovato A, de Filippis C, Marioni G. Upper airway symptoms in coronavirus disease 2019 (COVID-19). Am J Otolaryngol 2020; 41(3):102474.

4) Mao L, Jin H, Wang M, Hu Y, Chen S, He Q, et al. Neurologic manifestations of hospitalized patients with coronavirus disease 2019 in Wuhan, China. JAMA Neurol 2020;77(6):683-90.

5) Moein ST, Hashemian SM, Mansourafshar B, Khorram-Tousi A, Tabarsi P, Doty RL. Smell dysfunction: A biomarker for COVID-19. Int Forum Allergy Rhinol 2020;10(8):944-50.

6) Huart C, Philpott C, Konstantinidis I, Altundag A, Whitcroft KL, Trecca EMC, et al. Comparison of COVID-19 and common cold chemosensory dysfunction. Rhinology 2020;58(6):623-5.

7) Seiden AM. Postviral olfactory loss. Otolaryngol Clin North Am 2004;37(6):1159-66.

8) Beltrán-Corbellini Á, Chico-García JL, Martínez-Poles J, RodríguezJorge F, Natera-Villalba E, Gómez-Corral J, et al. Acute-onset smell and taste disorders in the context of COVID-19: A pilot multicentre polymerase chain reaction based case-control study. Eur J Neurol 2020;27(9):1738-41.

9) Gane SB, Kelly C, Hopkins C. Isolated sudden onset anosmia in COVID-19 infection. A novel syndrome? Rhinology 2020;58(3): 299-301.

10) Costa KVTD, Carnaúba ATL, Rocha KW, Andrade KCL, Ferreira SMS, Menezes PL. Olfactory and taste disorders in COVID-19: A systematic review. Braz J Otorhinolaryngol 2020;86(6):781-92.
11) Meng X, Deng Y, Dai Z, Meng Z. COVID-19 and anosmia: A review based on up-to-date knowledge. Am J Otolaryngol 2020; 41(5):102581

12) Lee $Y$, Min $P$, Lee S, Kim SW. Prevalence and duration of acute loss of smell or taste in COVID-19 patients. J Korean Med Sci 2020; 35(18):e174.

13) Vaira LA, Salzano G, Deiana G, De Riu G. Anosmia and ageusia: Common findings in COVID-19 patients. Laryngoscope 2020; 130(7):1787.

14) Vaira LA, Salzano G, Petrocelli M, Deiana G, Salzano FA, De Riu G. Validation of a self-administered olfactory and gustatory test for the remotely evaluation of COVID-19 patients in home quarantine. Head Neck 2020;42(7):1570-6.

15) Bagheri SH, Asghari A, Farhadi M, Shamshiri AR, Kabir A, Kamrava SK, et al. Coincidence of COVID-19 epidemic and olfactory dysfunction outbreak in Iran. Med J Islam Repub Iran 2020;34(6):62.

16) Dell'Era V, Farri F, Garzaro G, Gatto M, Aluffi Valletti P, Garzaro M. Smell and taste disorders during COVID-19 outbreak: Crosssectional study on 355 patients. Head Neck 2020;42(7):1591-6.

17) Hopkins C, Surda P, Whitehead E, Kumar BN. Early recovery following new onset anosmia during the COVID-19 pandemic - an observational cohort study. J Otolaryngol Head Neck Surg 2020; 49(1):26.

18) Kaye R, Chang CWD, Kazahaya K, Brereton J, Denneny JC 3rd. COVID-19 anosmia reporting tool: Initial findings. Otolaryngol Head Neck Surg 2020;163(1):132-4. 


\section{Supplementary Material 1}

\section{코로나19로 인한 후각 및 미각 장애 진단을 위한 설문조사}

성명

생년월일:

성별: 남, 여 작성일: 2020년

코로나19 감염 상태(의사 기입란): $\square$ 경증 $\square$ 중등증 $\square$ 중증 $\square$ 최중증

1. 코로나19 확진일은 언제입니까? 2020년 월 일

2. 코로나19 감염이 어떤 경로로 이루어졌습니까?
$\square$ 모르겠다
$\square$ 확진자와의 접촉
$\square$ 의료기관 종사자
$\square$ 응급의료요원
$\square$ 집단감염
$\square$ 유행지역 여행
$\square$ 기타 (
)

3. 평소 진단받았거나 현재 치료 중인 질병이나 위험인자가 있습니까? (복수선택가능)
$\square$ 없음 $\square$ 흡연 $\square$ 순환기계질환(고혈압, 심근경색, 뇌경색, 부정맥 등)
$\square$ 내분비계 및 대사성질환(당뇨병, 갑상성질환 등) $\square$ 정신질환(치매, 조현병 등)
$\square$ 호흡기계질환(천식, 만성폐쇄성폐질환, 폐렴 등) $\square$ 악성신생물(암)
$\square$ 비뇨생식기계질환(신장질환, 투석 등) $\square$ 신경계질환
$\square$ 소화기계질환 $\square$ 혈액 및 조혈계질환 $\square$ 모르겠다 $\square$ 기타 (

4. 이전에 병원에서 코질환이 있다고 진단받은 적이 있습니까? (복수선택가능)

$\square$ 없음 $\square$ 비염 $\square$ 부비동염(축농증) $\square$ 비중격만곡증 $\square$ 기타

5. 아래 항목 중 코로나19 감염 후 경험했던 증상을 모두 표시해 주세요. (복수선택가능)
$\square$ 후각장애
$\square$ 미각장애
$\square$ 열 $\square$ 오한
$\square$ 피로/권태감
$\square$ 기침
$\square$ 두통
$\square$ 인후통
$\square$ 코막힘
$\square$ 콧물
$\square$ 위장 장애
$\square$ 기타 (
$\square$ 없음

*** 아래 질문은 후각장애나 미각장애가 있는 분만 답해주세요. ***

6. 후각장애나 미각장애를 처음 인지한 것은 언제 인가요?

$\square$ 코로나19 감염 전부터 있었다 $\square$ 코로나19 감염 후에 발생했다 $\quad \square$ 모르겠다

7. 본인이 생각하기에 현재의 후각 및 미각장애의 원인은 무엇이라고 생각합니까?
$\square$ 코로나19
$\square$ 코질환(부비동염/물혹)
$\square$ 감기
$\square$ 사고(머리 외상)
$\square$ 모름
$\square$ 기타 (

8. 후각 및 미각장애가 생기기 전에 다른 증상(인후통, 발열 등)이 있었나요?
$\square$ 예
$\square$ 아니오

9. 후각 및 미각장애가 발생한 후 전반적인 컨디션의 변화가 있었나요?

$\square$ 악화되었다 $\square$ 호전되었다 $\square$ 변화 없다

10. 코로나19 감염 이전에도 감기 등으로 인하여 후각이나 미각장애를 경험한 적이 있었나요?

$\square$ 있다 $\square$ 없다 $\square$ 모르겠다

11. 후각 혹은 미각장애는 호전 되었나요?

$\square$ 예 $\square$ 아니오

12. 냄새나 맛을 느낄 수 있으나 평소와는 다른 냄새나 맛으로 느끼나요?

$\square$ 예 $\square$ 아니오

13. 코로나19 발병 당시 후각장애 정도를 표시해 주세요(해당 숫자에 동그라미해주세요)

\begin{tabular}{|c|l|l|l|l|l|l|l|l|l|l|}
\hline 0 & 1 & 2 & 3 & 4 & 5 & 6 & 7 & 8 & 9 & 10 \\
\hline
\end{tabular}

14. 현재의 후각장애 정도를 표시해 주세요.

\begin{tabular}{|c|c|c|c|c|c|c|c|c|c|c|}
\hline 0 & 1 & 2 & 3 & 4 & 5 & 6 & 7 & 8 & 9 & 10 \\
\hline
\end{tabular}

15.코로나19 발병 당시 미각장애 정도를 표시해 주세요.

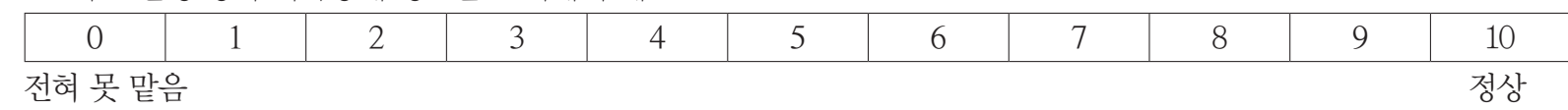

16. 현재의 미각장애 정도를 표시해 주세요.

\begin{tabular}{|c|c|c|c|c|c|c|c|c|c|c|}
\hline 0 & 1 & 2 & 3 & 4 & 5 & 6 & 7 & 8 & 9 & 10 \\
\hline
\end{tabular}

